ELORE (ISSN 1456-3010), vol. 20 - 1/2013.

Julkaisija: Suomen Kansantietouden Tutkijain Seura ry.

[http://www.elore.fi/arkisto/1_13/sarelin.pdf]

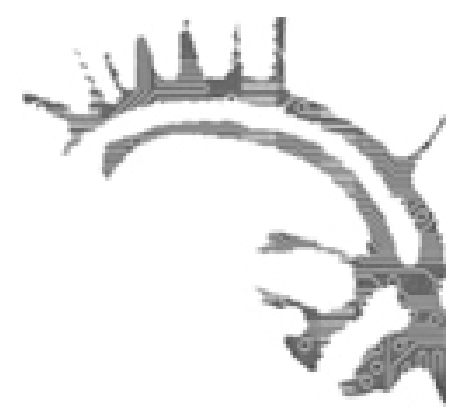

\title{
LECTIO
}

\section{OM MÖRKER, MASKULINITETER, HUMOR OCH LEK INOM BLACK METAL}

\author{
Mikael Sarelin
}

Lectio praecursoria, Abo Akademi 25.12013

Metal-musik är, trots att det under senare år har gjorts allt mera forskning i den, ett område där många aspekter fortsättningsvis förblivit relativt outforskade. En sådan aspekt som jag undersöker i min doktorsavhandling är genus, som ofta betraktas som den sociala och kulturella dimensionen av kön. Den globala metal-scenen, black metal inräknad, är mansdominerad i många bemärkelser. Metal har tidvis anklagats för att vara misogyn och chauvinistisk, samtidigt som en majoritet bland medlemmarna av metalscenen är män. Metal utgör en homosocial, mansdominerad miljö som bekräftar den maskulina hegemonin, manlig dominans i samhället. Detta sker genom vad som kallas för male bonding, att män uttrycker solidaritet med varandra i utrymmen där kvinnor inte finns representerade.

\section{BLACK METAL}

Black metal, den subgenre av metal som utgör föremål för min undersökning, har sina rötter i heavy metal. Black metal hör till de mest extrema subgenrerna inom metal- 
musikens breda fält, även kallade extreme-metal. Musiken inom vilken mellanregister och diskant vanligtvis framhävs, håller ofta ett högt tempo och domineras av distorterade elgitarrer, dubbla bastrummor och vad som kallas för blast beats, det vill säga att virveltrumman håller ett mycket högt tempo. Sången är i regel relativt gäll och skrikig vilket resulterar i att låttexterna är nästintill omöjliga att urskilja. Black metal-scenen är samhällskritisk och uttalat anti-kristlig och i regel är den inspirerad av satanistiska eller paganistiska tankegångar. Låttexterna som går hand i hand med black metals ideologiska dimension och det mörker som är centralt inom black metal och som jag strax ska återkomma till, kan exempelvis angripa kristendomen genom blasfemi, beskriva den vilda, otämjda naturen som mörkrets hemvist eller behandla mörker och antikristlighet ur mera personliga synvinklar.

Jag har redan hunnit nämna det för min avhandling centrala begreppet scen. Begreppet har två innebörder i min avhandling. För det första beskriver jag en konkret scen på vilken artisterna står och framför sin musik under spelningarna. För det andra utgör scen för mig ett teoretiskt och analytiskt begrepp med vars hjälp jag beskriver det som händer inom och runtomkring black metal. Scenbegreppet är ett så kallat postsubkulturellt begrepp. Postsubkulturella begrepp har i många sammanhang fått ersätta subkulturbegreppet, som har blivit för vagt och svårdefinierbart för att kunna användas som ett fruktbart teoretiskt verktyg. Enligt Keith Kahn-Harris som i en undersökning av extreme metal diskuterar begreppet scen, möjliggör det en förståelse av all den aktivitet som äger rum kring musiken, såsom musikskapande, skivdistribution och fan-aktivitet (Kahn-Harris 2007). Genom scenbegreppet går det att beskriva hur människor gör och konstruerar saker tillsammans inom ett visst utrymme. Scener kan förekomma på olika nivåer och överlappa varandra. Från små lokala scener till transnationella scener. Inom ramarna för min avhandling undersöker jag den finländska black metal-scenen.

\section{MASKuliniteter}

Medan huvudfåran inom metal, kanske särskilt heavy metal, har anklagats för att sexualisera kvinnan, för att göra henne till ett sexobjekt, inte minst genom att visa lättklädda kvinnor i musikvideor och på skivomslag, har black metal ofta presenterats som en scen inom vilken kön, eller genus, inte är av betydelse. Detta har motiverats, av bland andra Thomas Bossius, som har skrivit en doktorsavhandling i vilken bland annat black metal undersöks, med att genus inte framhävs inom black metal-scenen, att varken kvinno- eller manskroppen sexualiseras på samma vis som inom många andra metal-genrer (Bossius 2003). Detta är förvisso, med vissa undantag, sant, men samtidigt vill jag påpeka att också black metal-scenen är mansdominerad, scenmedlemmarna och $i$ än högre grad bandmedlemmarna, utgörs ju av män. I dylika homosociala miljöer blir genus av centralt värde, ett värde som är så centralt att det inte går att förbise. Det är i den homosociala miljö som finländsk black metal utgör som jag har undersökt gestaltningar av maskuliniteter genom att söka efter återkommande kulturella mönster. Jag har kommit fram till att det inom finländsk black metal förekommer två återkommande maskulinitetsgestaltningar som jag har valt att kalla för krigaren och transvestiten. 
Krigarmaskuliniteten utgör den dominerande, så kallade hegemoniska, maskuliniteten inom den finländska black metal-scenen medan transvestiten ifrågasätter det hegemoniska och det normativa inom den egna scenen. Både krigaren och transvestiten tar dock i enlighet med black metal-stilen avstånd från den kristna kyrkan genom en anti-kristlig ideologi.

Krigaren överdriver den maskulina hegemonins ideal, som utgörs av en stark, handlingskraftig man, genom att iklä sig en slags rustning som i klädväg oftast domineras av färgen svart och som kan bestå av bland annat läder, nitar, spikar och kedjor, inverterade kristna symboler och av vad som kallas för corpse paint, en ofta svart och vitfärgad ansiktsmålning som ger black metal-artisterna ett utseende som påminner om demoner eller levande döda. Krigaren har en sammansvetsande och bekräftande roll inom scenen: genom att upprepa element som har standardiserats inom black metal bekräftar han det normativa inom black metal-scenen.

Om krigarens roll inom black metal-scenen är normbekräftande, blir transvestitens uppgift att ifrågasätta det normativa, att hindra scenen från att stagnera. Transvestiten iscensätter en dragshow som driver med normativt genus, med manliga och kvinnliga normer. Dragshowen driver med det omgivande samhällets uppfattning av det heteronormativa, men också med black metal-scenens föreställningar om manligt och kvinnligt. Enligt Judith Butler skapas genus genom vad hon väljer att kalla för genusperformativitet (Butler 2005, 2007). Genom den dragshow som transvestiten iscensätter ifrågasätter han normativt genus, vad som kallas för heteronormativitet, och försöker genom sitt nyskapande hindra black metal-scenen från att stagnera.

\section{MörKER}

Inom den transnationella black metal-scenen ges ofta uttryck för ett mörker som är av centralt värde för scenmedlemmarna. Jag har intresserat mig för mörkrets betydelse inom den finländska black metal-scenen och undersökt hur medlemmar av den finländska scenen uppfattar och uttrycker mörker. Genom detta har jag kunnat konstatera, att mörkret inom finländsk black metal har religiösa betydelser, så gott som uteslutande anti-kristliga och ofta satanistiska, samt att mörkret fungerar som en markör för black metal som stil, en markör som uttrycks genom musik, låttexter samt på ett visuellt plan. Mörkret förses utåt med en aggressiv och kompromisslös aura av allvar, den utomstående får lätt en bild av black metal som en scen där det inte finns plats för skämt eller lek utan som drivs av en mörkrets ideologi och av en anti-kristlig samhällsprotest.

\section{HUMOR OCH LEK}

Hittills har jag diskuterat min egen avhandling, dess avgränsning och resultat. Nu övergår jag till att diskutera en annan aspekt av metal-musiken, utöver genus, som tillsvidare i hög grad har lyckats undgå forskarnas blickar, nämligen metal-scenens förhållande till 
humor och lek. Jag intresserar mig, enligt ramarna för min forskning, givetvis för black metal-scenens förhållande till humor och lek, något som jag mycket kort går in på i slutdiskussionen av min doktorsavhandling men som inte skulle ha fătt plats för den mycket omfattande diskussion som ämnet skulle kräva, i samma avhandling där genus och mörker undersöks.

Black metal kan lätt framstå som en det nattsvarta allvarets hemvist, vigd åt en mörkrets ideologi. Man kan föreställa sig att black metal-scenen är ett utrymme där det inte finns plats för varken lek eller humor. Men humor kan förekomma också i de mest allvarliga kontexter och lek kan finnas där den inte vid ett första ögonkast gör sig synlig. Enligt Johan Huizinga definieras leken av att den har sin egen mening som är avgränsad från vardagen och av att den är obegränsad av såväl kulturer som världsåskådning (Huizinga 1984). Jag vill argumentera för att det inom black metal-scenen finns utrymme för såväl lek som humor. Leken, påstår jag, omfattar både mörkret och det ideologiska inom black metal, vilket inte minst uttrycks genom transvestitens dragshow. Drag uppfattas i själva verket ofta som en lek med samhällsnormer, som en satir som driver med det heteronormativa. Detta drivande med sexuella normer blir mer än tydlig i transvestitens scenperformans i vilken bland annat korsetter, läppstift och såpbubblor ingår. Framför allt krigarens rustning i hela sin glans, med läder, nitar, spikar, antikristliga symboler, corpse paint och blod kan verka långt bortom all lek, men också krigarmaskuliniteten driver med det omgivande samhället genom att överskrida gränserna för det normativa. Genusforskaren Raewyn Connell har utvecklat begreppet protestmaskulinitet med vilket hon avser en överdrift av samhällets hegemoniska, normativa maskulinitet. Ofta är det unga män som söker efter sin plats i samhället som agerar protestmaskulint för att övervinna en känsla av maktlöshet, menar Connell (Connell 1995). Genom sin protestmaskulina, överdrivna gestaltning av hegemonisk maskulinitet som idoliserar en stark, handlingskraftig och rakryggad man, leker krigaren med samhällsnormerna i ett försök att frånta det normativas maktstrukturer och förse sig själv med dem i stället.

Det finns alltså lek inom black metal. Men inte heller humor saknas inom scenen. Humorn inom black metal riktas ofta mot den egna scenen i form av ironi. Scenmedlemmarna är mycket medvetna om det tidvis rentav överdrivna allvar som scenen är känd för och om artisternas utstyrsel som tidvis är så extrem att den kan te sig komisk. Genom att rikta humorn mot sig själva visar scenmedlemmarna att de kan ta ett steg bakåt och beskåda black metals stil och ideologiska dimension och förstå det humoristiska som finns inom den egna scenen. Med detta inte sagt att alla scenmedlemmar är beredda att se humor inom black metal, men band som det svenska Sportlov, som bestod av kända artister inom den svenska black metal-scenen och som blandade in vintersport i både ideologi, låttexter och det visuella inom black metal, torde räcka för att visa på humorns existens inom black metal.

Låttitlar som "Svart pist", "Offerblod i Vallabod" och "Bloddopad av Satan" berättar sin besynnerliga historia om ett band som uppträdde iförda slalomglasögon, pälsjackor och corpse paint och som blandade in humor i form av utförsåkning och snölekar i black metals mörka allvar.

Utöver det uppenbart humoristiska Sportlov och en handfull liknande band, vilka jag inte går in på här, förekommer också en mera subtil humor inom scenen, en humor som 
Mikael Sarelin: Om mörker, maskuliniteter, humor och lek inom black metal

inte är lika uppenbar som till exempel Sportlovs. Som exempel kunde nämnas finländska Impaled Nazarene, som jag vill påstå att gör humor genom att med avsikt överdriva sina låttexter, genom att göra dem så extrema att det humoristiska inom dem blir uppenbart. Så antar jag att är fallet bland annat gällande den starkt misogyna låten "Nyrkillä tapettava huora" som jag analyserar i min avhandling. Denna låttext är så överdriven och dess innehåll så extremt att jag utgår från att överdriften är medveten och i varje fall delvis ämnad som humor. Med detta sagt vill jag inte påstå att låttexten på grund av att den möjligtvis utgör ett exempel på svart humor inom black metal-scenen, blir mera legitim eller korrekt.

Den grova, samhällsnormöverträdande humorn utgör en möjlighet för scenmedlemmarna till att driva med och skratta åt sig själv, att ta avstånd från allvaret inom black metal, samtidigt som de samhällskritiska elementen som black metal-stilen bygger på, kvarstår. Humorn kan med andra ord fungera som en säkerhetsventil med vars hjälp man kan ta avstånd från den annars så allvarliga scenen.

Black metals, och också den transnationella metal-scenens förhållande till lek och humor är ett viktigt område som inverkar på scenens utformning och kan berätta om scenmedlemmarnas syn på sig själva och på samhället, inom vilket jag anser att det $\mathrm{i}$ framtiden finns skäl att bedriva fördjupad forskning.

Sarelin, Mikael 2013: Krigaren och transvestiten. Gestaltningar av mörker och maskuliniteter i funländsk black metal. Åbo: Åbo Akademis Förlag. I elektroniskt format: http:// www.doria.fi/handle/10024/87571

\section{LITTERATUR}

Bossius, Thomas 2003: Med framtiden i backspegeln. Black metal- och transkulturen. Göteborg: Daidalos.

Butler, Judith 2005: Könet Brinner! Texter i urval av Tiina Rosenberg. Natur och kultur.

Butler, Judith 2006: Genus ogjort: Kropp, begär och möjlig existens. Stockholm: Norstedts akademiska förlag.

Butler, Judith 2007: Genustrubbel. Feminism och identitetens subversion. Göteborg: Daidalos.

Connell, R.W. 1995: Masculinities. Cambridge: Polity Press.

Connell, R.W. 2000: The Men and the Boys. Berkley and Los Angeles, University of California Press.

Connell, R. W. 2003: Om genus. Göteborg: Daidalos.

Huizinga, Johan 1984: Leikkivä ihminen. Yritys kulttuurin leikkiaineksen mä̈rittelemiseksi. Provoo: WSOY.

Kahn-Harris, Keith 2007: Extreme Metal. Music and Culture on the Edge. Oxford: Berg.

Filosofie doktor Mikael Sarelin är projektforskare vid Svenska Litteratursällskapet i Finland. 